Please note that this is an earlier version of a chapter that is now published in: Feminist History of Philosophy: The Recovery and Evaluation of Women's Philosophical Thought, edited by Eileen O'Neill and Marcy Lascano (Dordrecht: Springer, 2019), pp. 319-36.

Please cite the published version.

\title{
Damaris Masham on Women and Liberty of Conscience
}

\author{
Jacqueline Broad
}

\begin{abstract}
In his correspondence, John Locke described his close friend Damaris Masham as 'a determined foe to ecclesiastical tyranny' and someone who had 'the greatest aversion to all persecution on account of religious matters.' In her short biography of Locke, Masham returned the compliment by commending Locke for convincing others that 'Liberty of Conscience is the unquestionable Right of Mankind.' These comments attest to Masham's personal commitment to the cause of religious liberty. Thus far, however, there has been no scholarly discussion of the tolerationist ethic underlying Masham's 1705 publication, Occasional Thoughts. In this chapter, I argue that Masham's work appeals to three common tolerationist principles of her time: the idea that the authorities should not use coercion and penalties as ways of imposing religious beliefs on others; the view that God requires human beings to attain salvation through their own efforts, and not by blindly following the dictates of the state-established religion; and the idea that the granting of liberty of conscience helps to ensure the peace and stability of political
\end{abstract}


society. I show that Masham goes further than her tolerationist contemporaries by

arguing that together these principles imply that a woman's intellectual education-or the conscious cultivation of a woman's ability to reflect critically on her religious beliefs-is vital for the good of the commonwealth.

KEYWORDS: Damaris Masham; early modern political thought; liberty of conscience; John Locke; women's education. 


\section{Damaris Masham on Women and Liberty of Conscience}

In a 1691 letter to the Dutch Remonstrant, Philippus van Limborch (1633-1712), John Locke (1632-1704) writes that

My hostess is a determined foe to ecclesiastical tyranny.... It is in vain, she believes, that so much noise is made everywhere about the reform of religion and the spreading of the Gospel so long as tyranny in the Church — force in matters of religion - as is generally the custom prevails under other names however specious and is commended. ${ }^{1}$

Locke's 'hostess' at this time was his close friend Damaris Cudworth Masham (16591708), and in this letter he also conveys Masham's interest in seeing the complete volume of Limborch's Historia Inquisitionis (1692), a history of religious persecution in Europe. These comments attest to Masham's personal commitment to the cause of religious toleration. In her lifetime, Masham wrote two short treatises of her own, A Discourse concerning the Love of God (1696) and Occasional Thoughts in Reference to a Vertuous or Christian Life (1705), both of which were published anonymously. ${ }^{2}$ Neither of these works has been studied for its opposition to 'ecclesiastical tyranny' or 'force in matters of religion.' In this paper, I argue that Masham's second work, the Occasional Thoughts, constitutes an original contribution to the early eighteenth-century discussion about liberty of conscience (or liberty of worship) in England. ${ }^{3}$

Today Masham is not typically thought of as a political writer, even though she makes explicit political comments in both her letters and her final treatise, the Occasional Thoughts. ${ }^{4}$ One scholar, Sarah Hutton, has pointed to thematic similarities between parts 
of Masham's Occasional Thoughts and Locke's Letter concerning Toleration (first published in Latin as Epistola de Tolerantia in 1689). But Hutton simply observes that like Locke in the Letter, Masham 'values virtuous living more highly than religious ceremonial. ${ }^{5}$ More recently, Regan Penaluna argues in favor of seeing Occasional Thoughts as a political text with a definite program for social reform. ${ }^{6}$ And James Buickerood has pointed to Masham's early commitment to toleration in her letters to Locke. ${ }^{7}$ In his recent history of toleration, John Locke, Toleration, and Early Enlightenment Culture (2006), John Marshall also describes Masham as a 'tolerationist author,' but without explanation or evidence. ${ }^{8}$ So far, no one has interpreted Masham's final book in light of its engagement with the topical political themes of toleration and liberty of conscience.

In the first part of this chapter, I discuss the historical-intellectual background to Masham's work, and provide a brief account of Masham's association with the famous 'republic of letters' devoted to universal religious toleration and enlightenment in late seventeenth-century Europe. ${ }^{9}$ In the second part, I demonstrate that Masham expresses a commitment to three common tolerationist principles of her time: the view that authorities should not use coercion and penalties as ways of imposing religious beliefs on others; the idea that God requires human beings to attain salvation through their own efforts, and not by blindly following the dictates of the state-established religion; and the view that the granting of liberty of conscience helps to ensure the peace and stability of society. In the third and final part, I show that Masham argues that together these principles imply that a woman's intellectual education —or the conscious cultivation of a 
woman's ability to reflect critically on her religious beliefs - is vital to the flourishing of the commonwealth.

Before I begin, I would like to propose a brief revision to the standard histories of political thought for this period. In his authoritative work, John Marshall observes that while the ethos of the republic of letters 'held it open to both ladies and gentlemen, in these years [the late seventeenth century] female participants in its discussions and publications were relatively rare. ${ }^{10}$ A quick survey of the evidence shows that this is not strictly true. Masham was not the only early modern English woman to express her views about religious liberty and toleration in print. A few decades earlier, Margaret Cavendish (1623-73) had argued that, for the sake of peace and social harmony, subjects ought to be permitted liberty of conscience on the condition that they do not meddle with government. ${ }^{11}$ During and after the Glorious Revolution (1688-89), women were also active participants (on both sides) in the toleration debates-among them Elinor James (c. 1645-1719), Joan Whitrowe (fl. 1665-97), and Anne Docwra (c. 1624-1710). ${ }^{12}$ Some of these women echoed the calls for liberty of conscience of their civil war predecessors, such as Katherine Chidley and the Leveller women petitioners of the 1640s. In Masham's own time, Mary Astell (1666-1731) was an active pamphleteer on the antitolerationist side: in several anonymous tracts of 1704, she supported the conservative Tory position against the practice of occasional conformity. ${ }^{13}$ And in the eighteenth century, Catharine Trotter Cockburn (1679-1749) defended Locke's Christian credentials with reference to his Letter concerning Toleration. Cockburn cites Locke's argument that 'the less bias was put upon men's minds, either by civil advantages or disadvantages, the more likely they would be to discern truth, and to embrace it for it's [sic] own sake'-an 
argument that Masham also expresses in her work. ${ }^{14}$ These women all had something to contribute to the intellectual debates out of which our modern-day concept of toleration emerged; and their contributions — as modest as they sometimes were — are part of the complex history of tolerationist thought and practice. They are not so rare to warrant omission. I hope to show that Masham, moreover, is unique among her contemporaries in one important respect: she offers the only early eighteenth-century discourse about liberty of conscience to consider the implications for women's intellectual education. ${ }^{15}$

\section{The Historical and Intellectual Background}

Though Occasional Thoughts was published in 1705, in her Preface Masham says that the manuscript 'was written some years since' but that it had lain by 'for above two Years unread, and almost forgotten' (OT, sig. A2r). So it would appear that the work was originally composed in about 1702-03, a period of intense political controversy about the practice of occasional conformity and the toleration of non-conformist religious sects in England. As a result of the Toleration Act of 1689, Protestant dissenters-such as Quakers, Independents, and Baptists — began to enjoy a limited toleration in English society. During William III's reign, dissenters were eligible for government positions provided that they attended at least one Anglican church service per year. But religious toleration (or the practice of tolerating liberty of worship) was by no means a universally accepted ideal at this time. Upon William's death in 1702, High-Church Anglicans stepped up their campaign against the toleration of non-conformist religions and the practice of occasional conformity. In the first few weeks of Anne's reign in 1702, and then again in 1704, a group of Tories put forward the Occasional Conformity Bill in 
parliament in a bid to prevent non-conformists from taking communion in Anglican churches. Whigs and Tories fiercely debated the matter in print, with many Tories proposing the reinstitution of penalties for dissenters, and several Whigs presenting the case for religious toleration.

Despite its provocative title, Masham's Occasional Thoughts does not explicitly acknowledge the topical controversy about occasional conformity in England. ${ }^{16}$ But Masham and Locke were closely associated with an author who took part in the pamphlet warfare—John Shute, the first Viscount Barrington (1678-1734) and pro-tolerationist author of The Interest of England, \&c., with some Thoughts about Occasional Conformity (1703), and The Rights of Protestant Dissenters (1704). Upon hearing about Masham's death in April 1708, Shute wrote to her step-daughter, Esther Masham, saying that It was with a degree of greif that I cannot express, $\mathrm{y}^{\mathrm{t}} \mathrm{I}$ heard of my good Lady Masham's death accidentally when I was in Town ... it was $\mathrm{w}^{\text {th }}$ a great deal of ease to my mind that I found she $d y^{\prime} \mathrm{d} \mathrm{w}^{\text {th }}$ out pain, \& that $\mathrm{y}^{\mathrm{u}}$ have the satisfaction to know, that every thing was done for her that could be. Madam, I heartily condole with you upon the loss of so incomparable a Relation \& so agreable a Companion. ${ }^{17}$

Shute says that he revered Damaris Masham as a mother, loved her as a sister, and that 'by repeated Instances of a friendship of some years continuance,' she had given the greatest demonstration of her tender regard and good will for him. ${ }^{18}$ Masham was also the friend and correspondent of Anthony Ashley Cooper, the third Earl of Shaftesbury (1671-1713), another author with a commitment to religious liberty. ${ }^{19}$ And Masham's 
Occasional Thoughts was published by the Whig publisher, Awnsham Churchill (16581728), a known advocate of religious toleration. ${ }^{20}$

Given her background and upbringing, Masham's association with such supporters of toleration should not surprise us. Before her first meeting with Locke in about 1681, Masham had spent her early life among the theologians and philosophers at Cambridge University, including her father, Ralph Cudworth (1617-1688), and Henry More (1614-87). In another letter to Limborch, dated 18 June 1691, Locke says of Masham that 'as heiress to her father's kindliness she has the greatest aversion to all persecution on account of religious matters' (CJL, no. 1398). Locke undoubtedly refers to Cudworth's public reputation for Arminianism, or his tolerant attitude toward religious differences. In the mid-seventeenth century, the Cambridge Platonists were among the earliest English intellectuals to espouse the philosophy of Jacob Arminius (1560-1609), a theologian with a strong following in the Netherlands. Between 1667 and 1687, Cudworth and More were correspondents of the Dutch Arminians, Limborch and Jean Le Clerc (1657-1737). These men rejected the Calvinist doctrine of predestination in favor of the view that all human beings have the capacity to attain salvation through their own efforts. Rosalie Colie highlights the fact that these views were politically controversial: 'Committed to a belief in free will and the Biblical foundations of truth, the Arminians permitted greater freedom of worship than the Reformed Church approved. ${ }^{21}$ In her later years, Masham also numbered Limborch and Le Clerc among her correspondents, and she was an avid reader of their works. ${ }^{22}$

Like their Dutch counterparts, the English Arminians were committed to an irenic approach to differences in matters of religion. In his Sermon Preached before the 
Honourable House of Commons (1647), Cudworth opposes needless doctrinal disputes in favor of living sincerely according to Christ's dictates. ${ }^{23} \mathrm{He}$ emphasizes that all Christians are capable of obtaining salvation, regardless of their grasp of the finer points of theology. Masham was undoubtedly familiar with Cudworth's position. In a 1705 letter to Limborch, however, Masham confesses that, as a young girl, she was puzzled about the exact nature of her father's religious views. ${ }^{24}$ She says that she was once troubled that her father subscribed to the Thirty-Nine Articles, when in her view they contained so many Calvinist principles. Years later, she was pleased to learn that her father 'had something more to say for himself.' When asked, he said that he regretted once being so stupid to prefer a man for an academic post, simply because he subscribed to the Articles, while rejecting another (equally worthy) man simply because he held the beliefs that Cudworth himself now held. The man in question was an Arminian. ${ }^{25}$ In her correspondence with Le Clerc, Masham subscribes to Cudworth's views about creedal minimalism: she opposes quarrelling and controversy about religious matters that do not affect our salvation; ${ }^{26}$ and she expresses her dismay that 'Teachers of the People' cruelly attack 'some men onely for dissenting from them in Opinions which are no Doctrines of Christianitie. ${ }^{27}$

In his Explanation of the Grand Mystery of Godliness (1660), Henry More expresses an even stronger political commitment than that of Cudworth. More devotes two chapters to 'Liberty of Conscience' (book 10, chapters 10 and 11), in which he argues that 'there is an antecedent Right of Liberty of Conscience not to be invaded by the Civil Magistrate. ${ }^{28}$ It is plain, he says, that 'the Soveraign power of God sets the sincere Religionist free in matters of Religion from any external force or power 
whatsoever. ${ }^{29}$ As rational creatures, all human beings have the power to examine their religious beliefs for themselves and, if they come to dislike them, to exchange them for a better way of serving God. ${ }^{30}$ According to More, human beings must be permitted the liberty to change their religion if their conscience so dictates. He thus defends every man's inviolable right to freedom in religion, 'provided they be not degenerated into Atheisme and Prophaneness. ${ }^{31}$ The power of the civil magistrate is constrained and limited by this common right; and it is therefore unfitting that the magistrate use external force in religious matters.

Some scholars dispute the idea that Masham herself was an advocate of Cambridge Platonism. ${ }^{32}$ But regardless of whether or not Masham held their views as her own, the similarities between her religious outlook and that of the Platonists cannot be denied. Above all, like Cudworth and More, she highlights the importance of a lived Christianity, and a religious faith grounded in reason rather than dogma. Masham also echoes More's description of liberty of conscience as an unquestionable right. In Masham's short biography of Locke, in a letter to Jean Le Clerc of 1705, she suggests that although not everyone agrees that toleration will bring about the public good, they nevertheless agree that an individual's right to liberty of conscience should prevail: 'God be thanked we are happy enough to reap a universal advantage from most mens being now convinc'd that Liberty of Conscience is the unquestionable Right of Mankind. ${ }^{33}$ The sentiment that toleration has brought about the public good, and that liberty of conscience ought to be respected, figures prominently in Masham's Occasional Thoughts. 
In his Letter concerning Toleration, Locke also regards liberty of conscience as 'every mans natural Right. ${ }^{34}$ From late 1691 to 1704 - the period of Locke's residency in Masham's home in Essex—-Locke completed numerous works, including his Third Letter for Toleration (1692) and part of a Fourth Letter (written in 1704, and published posthumously in 1706). It is reasonable to assume that Masham was familiar with Locke's contributions to the subject of toleration, despite the fact that he kept his authorship of the Letter a secret till his death. In the letter to Le Clerc of 1705, she makes her comments on liberty of conscience whilst commending Locke for his contribution 'to the real Benefit of the Publick' in terms of 'rectifying so many mens Judgements as he has done, concerning Tolleration' ${ }^{35}$ It should not surprise us, then, to hear Locke's political views on liberty of conscience resonating in Masham's work.

2. Masham on Virtue, Liberty, and the Commonwealth Throughout Occasional Thoughts, Masham states that her purpose is not only to make a contribution to the long-term happiness or good of the individual (OT, 5-6), but also to the prosperity of the country (OT, 2 and 232), and the flourishing of the commonwealth $(O T, 95-6)$. She observes that within memory this heretofore sober Nation has been debauch'd from Principles of Vertue and Religion, to such an excess of Vice and Prophaneness, that it has been Fashionable to have no shame of the grossest Immoralities, and Men have thought even to recommend themseves [sic] by avow'd Impiety. A Change which could not be consider'd without extream regret by all who either were in earnest Christians, or who truly lov'd the Prosperity of their Country: And as upon this occasion there 
was reason to be sensible that nothing operates so powerfully as the example of Princes, some have been of later Years induc'd to hope for a revolution in our Manners, no less advantageous than what has hitherto secur'd those Civil and Religious Liberties, without which it is impossible for Vertue to subsist upon any People whatsoever $(O T, 4)$.

Masham suggests that the Glorious Revolution — or the 'Happy Revolution,' as she calls it elsewhere - brought about positive political changes resulting in the security of 'Civil and Religious Liberties. ${ }^{36}$ She sees the fall of James II, and the accession of William and Mary, as leading the country from an age of vice and persecution to an enlightened age of tolerance. True virtue, in her view, requires conditions of religious and civil liberty in order to flourish — conditions that the 1688-89 revolution helped to secure. But Masham seems aware that, with the dawning of the age of toleration, society as a whole faces another challenge. If the magistrate is no longer in a position forcibly to dictate the religious beliefs of her subjects, then how is virtue and piety supposed to flourish in society? How are subjects supposed to be directed onto the path of Christianity? A corrupt society, after all, requires more than a virtuous and pious role model in order to bring about a revolution in manners:

When Men's Practices have infected their Principles and Opinions; and these have had time again reciprocally to confirm them in their Vicious Habits and Customs, the whole Constitution is corrupted; and the Personal Vertue then of the Prince (however conspicuous) will not, without a concurrence of other means, influence farther than to make (it may be) some change in the Garb, or Fashion of Men's Vices $(O T, 5)$. 
Masham intends for her book to provide a practical solution to this problem of the cultivation of virtue and true religion within society. She proposes a way in which rational creatures might habituate themselves to 'examine their own Actions by the true Rules and Measures of their Duty' $(O T, 3)$. God has given human beings the use of their reason in order to discover that law ('the law of reason') by which they must regulate their actions. Virtue is 'the natural result of a sincere desire to conform in all things to the Law set us by our Maker' $(O T, 11)$; and to become virtuous, we must regulate our 'Actions by the Universal, and Eternal Law of Right' $(O T, 24){ }^{37}$ Revelation has an important role to play in this regulation, because it provides the primary motivation to virtue: the express promise of eternal rewards and punishments $(O T, 105)$. For this reason, according to Masham, virtue and religion must go hand in hand. When individuals stray from the law of reason and revelation, then the political order - as well as earthly and spiritual happiness - is placed in jeopardy. 'Those Breaches of the Eternal Law of Reason ... disorder Common-wealths and Kingdoms; disturb the Peace of Families; and make by far the greatest part of the Private Infelicities of Particular Persons in this World.' They also 'render Men miserable in a future Life' $(O T, 2)$.

Masham's principal solution concerns the proper education of members of society, and the bulk of her book is an account of the principles upon which such an education must be based. She mentions the importance of executing just laws against immorality and 'prophaneness,' but 'a right care had of Education,' she says, 'is the only humane means of making People truly Vertuous' $(O T, 5)$.

Whenever our inferiour Magistrates shall be such as will be a terror to Evil doers, and encouragers to those who do well, and when Parents shall be perswaded that it 
is in their power to procure to their Children more valuable Treasures than Riches and Honours; the ancient Vertue of our Ancestors will then quickly be equall'd, if not surpass'd, by that of their Posterity: But till then, it is in vain to expect that any great Advances should be made toward an Amendment, as necessary to our present and National, as to our Personal and Future Happiness (OT, 5-6).

When a due regard is had for education, 'Commonwealths and Kingdoms have flourished, and become famous' $(O T, 6)$.

The first principle of a good education is that every individual must be permitted the liberty to examine and to question their moral and religious beliefs for themselves. In a letter to Gottfried Wilhelm Leibniz, dated 8 August 1704, Masham says that 'as I am a true English woman, I cannot but naturally have a Passion for Libertie in all senses. ${ }^{38}$ By 'all senses' of the word, Masham seems to mean liberty in its political, religious, and philosophical senses - she draws on all three concepts to support her case in Occasional Thoughts. First, in the political sense of liberty, Masham argues that every individual must be free from the threat of external force or coercion when it comes to their religious beliefs. On this subject, Masham's arguments bear some similarity to those of John Locke. In his Letter concerning Toleration, Locke presents several arguments in favor of the toleration of non-conformists in England. He begins by asserting the religious view that God has placed each man's salvation in his own hands, and that attaining this salvation requires that a man have an 'inward and full perswasion of the mind. ${ }^{39}$ For this reason, God has never given 'such Authority to one Man over another, as to compell anyone to his Religion. ${ }^{40}$ God requires individuals to come to the true religion through their own sincere efforts, and not through the compulsion of others. Locke's arguments 
also rely on an epistemological point: the idea that 'Such is the nature of the Understanding, that it cannot be compell'd to the belief of any thing by outward force. ${ }^{41}$ Locke says that while someone might compel us to act as though we believe in the Christian religion - through penalties and threats, for example — no one can force us into believing the articles of faith: 'It is only Light and Evidence that can work a change in Mens Opinions. ${ }^{42}$ Locke points out that while magistrates might be born into certain privileges of wealth and power, these privileges do not extend to a certain knowledge of the one true religion: 'The one only narrow way which leads to Heaven is not better known to the Magistrate than to private Persons and therefore I cannot safely take him for my Guide, who may probably be as ignorant of the way as myself, and who certainly is less concerned for my salvation than I myself am. ${ }^{43}$ So the magistrate simply does not have the authority to ask someone to quit the light of their reason, and "blindly resign up themselves to the Will of their Governors. ${ }^{44}$ If this were the case, then 'Men would owe their eternal Happiness or Misery to the place of their Nativity,' and their salvation would be merely a matter of chance. ${ }^{45}$

In sum, Locke holds that it is pointless and unfitting for the magistrate to force unbelievers into an outward show of conformity to the state religion. An individual's salvation and acceptance before God depends upon an inward sincerity, not the outward appearance of faith; and 'men cannot be forced to be saved whether they will or no. ${ }^{, 46}$ The use of force against unbelievers is likely to lead only to dissent, revolution, and war. 'Just and moderate Governments,' Locke says, 'are every where quiet, every where safe. But Oppression raises Ferments, and makes men struggle to cast off an uneasie and tyrannical Yoke. ${ }^{47}$ For magistrates, then, the toleration of religious differences, and the 
legal granting of liberty of conscience, is the best path to take for the sake of peace and security in the commonwealth.

Masham does not explicitly refer to Locke's Letter concerning Toleration, though she does cite 'a late Treatise intitled The reasonableness of Christianity as delivered in the Scriptures' $(O T, 109)$, and 'Mr. L—s excellent Treatise of Education' $(O T, 185)$. There are also oblique references to the epistemology of the Essay concerning Human Understanding. ${ }^{48}$ Nevertheless, like Locke in the Letter, Masham subscribes to the view that coercion and penalties should not be used as ways of inducing religious belief; that God requires individuals to attain salvation through their own efforts, and not by blindly following the dictates of others; and that the granting of liberty of conscience helps to maintain the order and well-being of political society.

To begin with, Masham opposes the use of punishment for religious doubts. She highlights the tale of 'a good Lady of the Church of Rome' who instructs her child in the doctrine of transubstantiation. When the girl expresses her disbelief, her mother replies 'What? do you not believe in Transubstantiation? You are a naughty Girl, and must be whip' $d$ ' $(O T, 39)$. Masham observes that 'instead of having their reasonable Inquiries satisfy'd, and incourag'd, Children are ordinarily rebuk'd for making any' (OT, 39-40). Such practices are not confined to Catholic nations alone. 'We generally indeed exclaim against the Cruelties of the Roman Church exercis'd over Men, on account or pretence of Religion. And it is true, that they have excell'd herein; yet all Parties among us, proportionally to the extent of their Power, have practis'd the same thing, and the Best, when restrain'd from it by the Civil Magistrate, make it evidently appear, that they bear that restraint uneasily' $(O T, 127)$. With this comment, Masham extends her analysis 
beyond the punishment of children to the punitive practices of those with political authority. It is reasonable to suppose that Masham alludes to the political climate in early eighteenth-century England, in which some parties were eager to reintroduce penalties for dissenters. Against such a stance, Masham maintains that, even in the early education of children, the imposing of penalties for religious doubts can have negative consequences. This is because, after a short time, children dare not question their religious teachers, and simply profess that 'that they do Believe whatever their Teacher tells them they must Believe, whilst in Truth they remain in an ignorant unbelief' $(O T, 39-40)$. An implicit faith can be potentially harmful for both the individual and society: in the first case, the individual is left vulnerable to the 'the most pitiful Arguments of the Atheistical' and her salvation is thus placed at risk $(O T, 39)$; in the second, the country is exposed to all the political upheavals that necessarily result from atheism and scepticism. If an individual is uninformed about the rational principles underlying her beliefs, then she might come to believe that 'All Religions are, alike, the Inventions and Artifices of cunning Men to govern the World by; unworthy of imposing upon such as have their good Sense: That Fools only, and Ignorants are kept in Awe, and restrained by their Precepts' (OT, 209). Masham's principal reasons for opposing punishment and cruelties for religious doubts diverge from those of Locke. She does not make the epistemological point that religious belief is involuntary, or that the magistrate does not have certain knowledge of the one true religion, but rather highlights the negative social and spiritual consequences of expecting children to believe without knowing why. Her point is not that religious belief cannot be forced, but rather that it should not be forced, for pragmatic or consequentialist reasons. But Masham does implicitly support Locke's view that atheism 
is detrimental to political stability. Locke did not extend toleration to atheists on the grounds that 'Promises, Covenants, and Oaths, which are the Bonds of Humane Society, can have no hold upon an Atheist' ${ }^{49}$ Atheists were therefore a threat to the peace and security of the state, and did not have the right to be tolerated. Likewise, in Masham's view, the spread of atheism threatens to ruin the government. Religious belief should not be forced upon individuals, she says, because the fear of punishment is likely to lead to a blind faith, and this, in turn, has the potential to lead to atheism. Those who are 'accustom'd to Believe without any Evidence of Reason for what they Believe' $(O T, 31)$ are more susceptible to the belief that there is no God. And a 'general Contempt of Religion towards God', Masham says, is always a forerunner of 'approaching Ruine to the best and most flourishing Governments which have been in the World' $(O T, 232)$.

Masham also maintains that virtue should not be defined in terms of passive obedience to the national church or to the dictates of one's country:

By a Vertuous Man, in all Countries of the World, or less Societies of Men, is commonly meant, by those who so call any one, such a Man as steadily adheres to that Rule of his Actions which is establish'd for a Rule in his Country Tribe, or Society, be that what it will. Hence it has been that Vertue has in different Times and Places chang'd Face, and sometimes so far, as that what has been esteem'd Vertue in one Age, and in one Country, has been look'd upon as quite the contrary in others $(O T, 84-5$; see also 96).

This historical fact, about the markedly different (and sometimes contradictory) definitions of virtue in different periods and countries, provides further support for Masham's argument that men must not be expected simply to believe what they are told 
to believe. In such countries, 'the Injunctions of some Lawgiver' $(O T, 85)$ are considered obligatory — not because they are 'Precepts of the Eternal Law of Right,' but because they are 'part of the Law, or Fashion of that Country, or Society' $(O T, 86)$. While this places an obligation of obedience upon men, their obligation is not based upon fixed and immutable moral rules, and it is therefore precarious. Masham defines a virtuous man in rather different terms: in her view, he is a man who judges what is right and wrong by 'the true rule of Reason' $(O T, 96)$. The measure of the virtuous man's actions is the law of reason, which is 'no Arbitrary thing, it being founded on Relations, and Connexions, which are as immutable as that determinate constitution in Things, which makes everything what it is' $(O T, 98)$. Likewise, a religious man cannot be someone 'whose Interest it has been to keep up the Credit and Authority of vain Traditions and superstitious Practices' $(O T, 97)$. Religion and virtue, in other words, need to be distinguished from 'the most Arbitrary Institutions of Men' in order to be stable and lasting in society $(O T, 100)$. Otherwise a Christian can give no more reason for his beliefs and practices than 'a Mahumetan' — that is, that 'their God fathers and God mothers ingag'd for them that they should believe so' $(O T, 47)$. This statement partly echoes Locke's view that an individual's religion should not simply be a matter of that 'which either Ignorance, Ambition, or Superstition had chanced to establish in the Countries where they were born. ${ }^{50}$

For Masham, a rational education is the key to bringing about a truly virtuous society. She emphasizes that children should never be rebuked for having doubts about their religious instruction. Teachers must endeavor to remove such doubts with solid argument, but at the same time give children the freedom to examine the grounds of their 
beliefs for themselves $(O T, 41)$. In other words, Masham advocates religious liberty, or the freedom to believe and worship as the individual sees fit. She recommends that It should ... be effectually Taught, and not in Words alone, That it is our Duty to study and examine the Scriptures, to the end of seeing therein what God requires of us to believe, and to $d o$. But none are effectually, or sincerely taught this, if notwithstanding that this is sometimes told them, they are yet not left at liberty to believe, or not believe, according to what, upon examination, appears to them to be the sense of the Scriptures $(O T, 44)$.

Children should have 'a liberty of fairly examining' $(O T, 45)$, so that they never come to believe that their religious instruction has been an imposition upon their reason. This practice is necessary in order to preclude men becoming unbelievers. Here again Masham's sentiments are reminiscent of those of Locke in the Letter. She emphasizes that the individual's primary duty is to determine what God requires us to believe and to do, and that this duty has priority over any duty to terrestrial authorities, including parents, teachers, and other spiritual directors.

\section{Masham's Argument for Women's Education}

We now turn to Masham's principal solution to the practical problem of bringing about a reformation of manners in a corrupt society: the intellectual education of women. As we have seen, Masham suggests that the legal granting of political and religious liberty, in itself, is not sufficient to set men on the right path to virtue. She observes that

Before we come to such a ripeness of understanding as to be capable by unassisted Reason to discover from the Nature of Things the just measures of our Actions, 
together with the obligations we are under to comply therewithal, an evil indulgence of our Inclinations has commonly establish'd Habits in us too strong to be overrul'd by the Force of Arguments $(O T, 53)$.

Masham describes the common human tendency to act in opposition to what our reason tells us is the morally best thing to do, a condition that ancient philosophers call akrasia. In such cases, the freedom to question our beliefs, and to subject them to the light of our reason, is not enough to make us virtuous agents, because we might already be disposed to moral weakness in so far as our reason is hopelessly enslaved by our passions and appetites. This 'enslavement' accounts for the fact that virtue tends to wear different 'faces' in different cultures and periods. Despite the universality of reason, human beings fail to embrace the eternal and immutable principles of morality because their habitual inclinations are corrupted in their early years (by their culture and cultural leaders or their families and educators, and so on). The right instruction regarding virtue thus requires not only 'good Principles' but also the inculcation of 'early Habits' (OT, sig. A3r).

One of the central theses of Masham's book is that if women are educated to become wise and virtuous, then this will contribute to the flourishing of the nation. As educated beings, and in their capacity as mothers, women will be able to impart a useful education to their offspring. Masham says that

But natural Affection apart, it should be consider'd by these, that no one is Born into the World to live idly; enjoying the Fruit and Benefit of other Peoples Labours, without contributing reciprocally some way or other, to the good of the Community answerably to that Station wherein God (the common Father of all) has plac'd them, who has evidently intended Humane kind for Society and mutual Communion, as 
Members of the same Body, useful every one each to other in their respective places. Now in what can Women whose Condition puts them above all the Necessities or Cares of a mean or scanty Fortune, at once so honourably and so usefully, both to themselves and others, be employ'd in as in looking after the Education and Instruction of their own Children? $(O T, 180)$

Masham's proposal applies to all women, including those among the 'common People,' since 'the Relation between Mother and Child is equal amongst all Ranks of people' (OT, 177). But Masham directs her main suggestions to the 'superior ranks of Persons' (OT, 160). She believes that it is especially important for 'ladies of quality' to assist those members of society who are likely to be of consequence to the commonwealth $(O T, 180)$, and who will play a part in the making and executing of laws $(O T, 170)$.

In their capacity as mothers, women have a profoundly significant role to play in society, in so far as they have a 'strong and unalterable influence upon their [children's] future Inclinations and Passions' $(O T, 8)$. From a young age, children must be taught to use their reason in order to overcome the temptations of 'present pleasure.' As flesh and blood, every human being faces the difficulty that our 'love of present pleasure' and our immediate desires subject our reason 'to an Unjust and Arbitrary Dominion ... A thing manifest not only in the instances here and there, but in the examples of whole Nations' $(O T, 83)$. But, as human beings, we are also free agents in the philosophical sense of being at liberty to act or not to act in accordance with our reason. Masham says that We being then indu'd, as we are ... with a liberty of acting, or not, suitably and agreeably hereunto; whence we can, according to the preference of our own minds, act either in conformity to, or disconformity with, the will of the Creator 
(manifested in his works no less than the will of any humane architect is in his) it follows, that to act answerably to the nature of such beings as we are, requires that we attentively examine, and consider the several natures of things, so far as they have any relation to our actions $(O T, 64-5)$.

God has given us 'Freedom or Liberty of Action' (OT, 69-70), such that we might either act contrary to the will of God or attain self-excellence through our own efforts. The attainment of self-excellence requires an attentive examination of alternatives, so that we might choose the path that will best ensure our long-term happiness. The involvement of mothers in early childhood education is conducive toward 'the right forming of the Minds' of both sexes $(O T, 8)$. If a woman herself has some training in languages, religion, and 'the useful Sciences' $(O T, 192)$, and she assists in her child's tuition for the first decade or so, then this is bound to have a positive influence on the child's moral development. She will act as a positive intellectual role model for her child to learn from. But a woman's education has intrinsic as well as instrumental value. Regardless of sex and social status, religion is 'the Duty of all Persons to understand' $(O T, 159)$; and to meet this duty, women must improve their understandings. Yet most women could not even explain the grounds of their Christian faith to 'a rational Heathen' $(O T, 161)$. As a matter of custom, a woman is expected only 'to believe and practice what she is taught at Church, or in such Books of Piety as shall be recommended to her by her Parents, or some Spiritual Director' $(O T, 207)$. She therefore has the same reason for going to an Anglican Church as she would 'have had to go to Mass, or even to the Synagogue,' had she been brought up a Catholic or a Jew $(O T, 208)$. As a consequence, women are easily persuaded by those men who wish to convert them to a different religion, or to talk them 
out of religion altogether. For the sake of their salvation, women need to grasp the underlying principles of the Christian religion and the reasons for their faith. Keeping them in the dark is in fact an 'injustice' to women $(O T, 191)$.

For if Christianity be a Religion from God, and Women have Souls to be sav'd as well as Men; to know what this Religion consists in, and to understand the grounds on which it is to be receiv'd, can be no more than necessary Knowledge to a Woman, as well as to a Man $(O T, 166)$.

Women require the same freedom of conscience or freedom of worship that is the birthright of all human beings. Christian women need to be taught that 'what they have learn'd to be their Duty is not grounded upon the uncertain and variable Opinion of Men' $(O T, 17)$.

Once again, Masham's point is that human beings are obliged to determine the nature of their duties to God for themselves. These spiritual duties have priority over any duties that women might have to their earthly superiors, including men as a social group. Women should not be brought up to have 'such a Notion of Honour as if the Praise of Men ought to be the Supreme Object of their Desires, and the great Motive with them to Vertue' $(O T, 21)$. Rather, women should be permitted the freedom to think for themselves and to interpret the Scriptures by the light of their reason. In this way, they will be duly protected from the specious arguments of sceptics and atheists; and in this way, a Christian commonwealth might be truly safeguarded against the twin threats of scepticism and atheism. 
In his 1691 letter to Limborch, Locke tells of Damaris Masham's opposition to ecclesiastical tyranny and to 'force in matters of religion' (CJL, no. 1429). In her Occasional Thoughts, we see this opposition expressed in writing. Though Masham's work is not typically interpreted as a political text, in it Masham demonstrates a commitment to several key tolerationist principles. She argues that, in order to be truly virtuous, and to live a life in conformity with God's will, human beings require the freedom to search the Scriptures for themselves, and to understand why they believe the Christian religion. If individuals do not have freedom of conscience (or freedom of worship), and are forced into an implicit faith, or into simply believing without knowing why, then they are more likely to fall prey to atheism and scepticism. This fall from true virtue and Christianity can have negative consequences for both the individual and for civil society - the spread of atheism can be the harbinger of ruin for a nation. Thus, according to Masham, human beings should not be forced or compelled into their religious beliefs by their superiors - their spiritual duty (to obtain salvation) should always have precedence over any duty of obedience that they might have to earthly authorities.

Masham's ideas have much in common with those of Locke and his colleagues in the late seventeenth-century republic of letters. In his Letter concerning Toleration, Locke regards liberty of conscience as 'every mans natural Right', provided that they do not disturb the peace and security of civil society. ${ }^{51}$ By 'every man,' it is natural to suppose that Locke means 'every human being', and that his tolerationist ethic extends to women as well as men. But Locke's explicit stance on the subject of women and liberty of conscience is far from clear. In his Paraphrase and Notes on the First Epistle of St 
Paul to the Corinthians (first published posthumously in 1706), Locke attempts to reconcile two seemingly contradictory propositions: first, the Apostle's declaration that women are forbidden to speak in church; and second, the view that women should be covered when they pray or prophesy in church. Locke explains the first proposition as a means of averting the suspicion that the Christian religion 'took away the Subordination of the Sexes, and set Women at Liberty from their natural Subjection to the Man. ${ }^{52}$ In the second case, Locke argues that St Paul permits women to pray or prophesy in church only when they are endowed with "extraordinary Gifts given by the Spirit of God. ${ }^{53}$ But even then, they must cover their heads so that 'the Subjection of their Sex should not be forgotten. ${ }^{54}$ With these remarks, Locke appears to affirm that ordinary women, without any special calling from God, are not permitted to be spiritual 'Teachers and Instructers' of the people. ${ }^{55}$ And when it comes to public religious worship, women must bow to the spiritual authority of men, and never act upon the 'Knowledge or Presumption of their own Abilities. ${ }^{56}$ It is possible, of course, that Locke thought that women could pursue religious worship in private without deferring to the 'Superiority and Dominion of the Man. ${ }^{57}$ But even so, it is difficult to reconcile his remarks in the Paraphrase and Notes with the idea that women have a universal right to pursue their own religious worship as their conscience so dictates.

By contrast, Masham points out that without the liberty to examine and understand the Scriptures according to her own reason, each woman's salvation is dependent merely upon the chance religious persuasion of her husband or father. For Masham, this is unacceptable: the implicit faith of women, like the implicit faith of men, can have ill consequences for society as a whole. Masham proposes that women be given 
a rational education such that they might be able to make a positive contribution to the moral and political well-being of future generations. She points out that, among her contemporaries, even the most solicitous about education have 'employ'd their care herein but by halves,' because 'the information and improvement of the Understanding by useful Knowledge (a thing highly necessary to the right regulation of the Manners) is commonly very little thought of in reference to one whole Sex' $(O T, 7)$. Yet a woman's education is important for the sake of her own spiritual welfare, as well as the welfare of the nation.

It is unlikely that Masham intended to provide a critique of Locke's views about women - there is certainly no textual evidence that she meant to challenge Locke's claims about women's natural subordination to men. ${ }^{58}$ It remains, however, that with her own contribution to the early modern republic of letters, Masham took a step further than Locke. By including women among those whose 'Birthright it is not blindly to Believe, but to Examine their Religion' $(O T, 171)$, Masham explicitly extends the tolerationist ethos of her time to the female sex..$^{59}$ 
* The following abbreviations will be used in this chapter:

CJL: John Locke, The Correspondence of John Locke, ed. E. S. de Beer, 8 vols. (Oxford: Clarendon Press, 1976-82).

OT: Damaris Masham, Occasional Thoughts in Reference to a Vertuous or Christian Life (London: A. and J. Churchil, 1705).

${ }^{1}$ John Locke, The Correspondence of John Locke, ed. E. S. de Beer, 8 vols. (Oxford: Clarendon Press, 1976-82), vol. IV, no. 1429. See also letters no. 1375 and 1398.

2 Damaris Masham, A Discourse Concerning the Love of God (London: Awnsham and John Churchil, 1696); and Damaris Masham, Occasional Thoughts in Reference to a Vertuous or Christian Life (London: A. and J. Churchil, 1705). For a facsimile reprint of these works, see The Philosophical Works of Damaris, Lady Masham, introduced by James G. Buickerood (Bristol: Thoemmes Continuum, 2004). The first attribution of Occasional Thoughts to Masham was in 1731. See the note by 'Philalethes' [Edward Northey], in Elizabeth Thomas and Richard Gwinnett, Pylades and Corinna: or, Memoirs of the Lives, Amours, and Writings of Richard Gwinnett ... and Mrs. Elizabeth Thomas (London: Edmund Curll, 1731), 93. Northey may have learnt of Masham's authorship from the publisher, Awnsham Churchill, who had died only three years earlier in 1728. There is no earlier (or more reliable) evidence of attribution. A 1721 copyright auction catalogue simply lists the work as 'Occasional Thoughts, 12 mo. The whole, with 378 of the said book'; see [Anonymous], At the Queens Head Tavern in Pater-Noster Row ... The following Copies and Parts of Copies of Mr. A. Churchill ([London]: n.p., 1721), 3. 
${ }^{3}$ In this chapter, I use 'liberty of conscience' interchangeably with 'liberty of worship'. On this subject in Locke, see John Dunn, 'The Claim to Freedom of Conscience: Freedom of Speech, Freedom of Thought, Freedom of Worship?' in From Persecution to Toleration: The Glorious Revolution and Religion in England, ed. Ole Peter Grell, Jonathan I. Israel, and Nicholas Tyacke (Oxford: Clarendon Press, 1991), 171-93. ${ }^{4}$ Masham is more commonly regarded as a theologian or a metaphysician. On her metaphysical views, see Jacqueline Broad, Women Philosophers of the Seventeenth Century (Cambridge: Cambridge University Press, 2002), 114-40.

${ }^{5}$ Sarah Hutton, 'Damaris Cudworth, Lady Masham: Between Platonism and Enlightenment,' British Journal for the History of Philosophy 1, 1 (1993): 37.

${ }^{6}$ Regan Penaluna, 'The Social and Political Thought of Damaris Cudworth Masham,' in Virtue, Liberty, and Toleration: Political Ideas of European Women, 1400-1800, ed. Jacqueline Broad and Karen Green (Dordrecht: Springer, 2007), 111-22.

${ }^{7}$ See James G. Buickerood, Introduction to Masham, Philosophical Works, xiii. Buickerood defends his claim in an as-yet unpublished paper, 'John Locke's "little French Man” and Damaris, Lady Masham's Initial Response to his Essay.' See also James G. Buickerood, 'What Is it With Damaris, Lady Masham? The Historiography of One Early Modern Woman Philosopher', Locke Studies: An Annual Journal of Locke Research 5 (2005): 179-214. For the letters, see Locke, Correspondence, nos. 967, 975, and 1003. In letter 967, Masham remarks that she is 'much in Love with the Author' of Commentaire Philosophique [Philosophical Commentary] — the famous tolerationist work of Pierre Bayle. 
${ }^{8}$ John Marshall, John Locke, Toleration and Early Enlightenment Culture: Religious Intolerance and Arguments for Religious Toleration in Early Modern Europe and 'Early Enlightenment' Europe (Cambridge: Cambridge University Press, 2006), 492.

${ }^{9}$ On the republic of letters, see Marshall, John Locke, Toleration and Early Enlightenment Culture, part III. For one of the earliest discussions of Masham in this context, see Luisa Simonutti, 'Damaris Cudworth Masham: una Lady della Repubblica delle Lettere,' in Scritti in Onore di Eugenio Garin (Pisa: Scuola Normale Superioire, 1987), 141-65.

${ }^{10}$ Marshall, John Locke, Toleration and Early Enlightenment Culture, 508.

${ }^{11}$ See Margaret Cavendish, Orations of Divers Sorts, Accommodated to Divers Places (1662), in Political Writings, ed. Susan James, Cambridge Texts in the History of Political Thought (Cambridge: Cambridge University Press, 2003), 167-8; and Margaret Cavendish, Grounds of Natural Philosophy: Divided into Thirteen Parts: With an Appendix containing Five Parts, with an introduction by Colette V. Michael, facsimile reprint of 1668 edition (West Cornwall, CT: Locust Hill Press, 1996), Appendix, 249. ${ }^{12}$ See Jacqueline Broad and Karen Green, A History of Women's Political Thought in Europe, 1400-1700 (Cambridge: Cambridge University Press, 2009), ch. 10; and Lois G. Schwoerer, 'Women and the Glorious Revolution,' Albion: A Quarterly Journal concerned with British Studies 18, 2 (1986): 195-218.

${ }^{13}$ See Mary Astell, Astell: Political Writings, ed. Patricia Springborg, Cambridge Texts in the History of Political Thought (Cambridge: Cambridge University Press, 1996). 
${ }^{14}$ Catharine Trotter Cockburn, Vindication of Mr. Locke's Christian Principles, in The Works of Mrs Catharine Cockburn, Theological, Moral, Dramatic, and Poetical, ed. Thomas Birch, 2 vols. (London: J. and P. Knapton, 1751), vol. II, 224.

15 Masham's contemporary Mary Astell considers the evils of a blind faith for women, but she does not base her arguments on tolerationist principles. On Astell on this issue, see the chapter by Hilda Smith in this volume.

${ }^{16}$ Another anonymous work with a similar title, Occasional Thoughts Concerning Our Present Divisions, And Their Remedies (London: John Nutt, 1704), does address the subject of occasional conformity.

17 John Shute (later Lord Barrington) to Esther Masham, 27 April 1708; in Esther Masham, 'Letters from Relations \& Friends to E. Masham 1722 Book 1st', in The Newberry Library, Chicago, Case MS E5.M3827, fols. 323-4. My transcription is from a photocopy of this manuscript in the Bodleian Library, Oxford, MS facs.e. 54.

18 Ibid.

${ }^{19}$ For Masham's two letters to Shaftesbury, see the Public Record Office, London, MS 30/24/20 [part II], no. 106, ff. 266-7; and MS 30/24/20 [part II], no. 109, ff. 273-4.

${ }^{20}$ Churchill was also Locke's publisher, book dealer, and financial agent. On Awnsham Churchill, and his co-publisher and brother John Churchill (c.1663-c.1714), see Mark Knights, 'Churchill, Awnsham (1658-1728)', in Oxford Dictionary of National Biography (Oxford: Oxford University Press, 2004).

${ }^{21}$ Rosalie Colie, Light and the Enlightenment: A Study of the Cambridge Platonists and the Dutch Arminians (Cambridge: Cambridge University Press, 1957), 11. 
${ }^{22}$ For the Masham-Limborch correspondence, see Amsterdam University Library (UVA), MS III.D.16, f. 215v; MS M.31.a; MS III.D.16, f. 53; MS M.31.b; MS III.D.16, f. 54; MS M.31.c; MS III.D.16, f. 55v-56. For Masham's letters to Le Clerc, see Amsterdam University Library (UVA), MS J.58v; MS J.57.b; MS J.57.a; MS. J.57.c. For a modern edition of Masham's letters to Le Clerc, see Jean Le Clerc, Epistolario, ed. Maria Grazia and Mario Sina, 4 vols. (Firenze: Leo S. Olschki, 1991), vol. II. For a recent transcription of Limborch's letters, see Luisa Simonutti, 'Religion, Philosophy, and Science: John Locke and Limborch's Circle in Amsterdam,' in Everything Connects: In Conference with Richard H. Popkin. Essays in His Honor, ed. James E. Force and David S. Katz (Leiden, Boston and Köln: Brill, 1999), 295-324.

${ }^{23}$ Ralph Cudworth, A Sermon Preached before the Honourable House of Commons, At Westminster, March 31. 1647 (Cambridge: Roger Daniel, 1647). On the political nature of this sermon, see G. A. J. Rogers, 'The Other-Worldly Philosophers and the Real World: The Cambridge Platonists, Theology and Politics,' in The Cambridge Platonists in Philosophical Context: Politics, Metaphysics and Religion, ed. G. A. J Rogers, J. M. Vienne, and Y. C. Yarka (Dordrecht/Boston/London: Kluwer Academic Publishers, 1997), 3-15.

${ }^{24}$ Damaris Masham to Philippus van Limborch, 17 September 1705; in the Amsterdam University Library (UVA), MS M.31.c.

${ }^{25}$ For Masham's account of her meeting with this man, see Damaris Masham to Philippus van Limborch, 17 September 1705; in the Amsterdam University Library (UVA), MS M.31.c. 
${ }^{26}$ Damaris Masham to Jean Le Clerc, May 1704; in the Amsterdam University Library (UVA), MS J.57.b.

${ }^{27}$ Damaris Masham to Jean Le Clerc, 21 June 1705; in the Amsterdam University Library (UVA), MS J.57.c.

${ }^{28}$ Henry More, An Explanation of the Grand Mystery of Godliness; Or, a True and Faithfull Representation of the Everlasting Gospel Of our Lord and Saviour Jesus Christ, the Onely Begotten Son of God and Sovereign over Men and Angels (London: J. Flesher, 1660), 515. On More's views about liberty, see G. A. J. Rogers, 'More, Locke and the Issue of Liberty,' in Henry More (1614-1687) Tercentenary Studies, ed. Sarah Hutton (Dordrecht: Kluwer Academic Publishers, 1990), 189-99.

${ }^{29}$ More, Grand Mystery of Godliness, 520.

${ }^{30}$ More, Grand Mystery of Godliness, 521.

${ }^{31}$ More, Grand Mystery of Godliness, 516.

${ }^{32}$ See Buickerood, 'What is it with Lady Masham?'.

${ }^{33}$ Damaris Masham to Jean Le Clerc, 12 January 1705; in the Amsterdam University Library (UVA), MS J.57.a.

${ }^{34}$ John Locke, A Letter Concerning Toleration, ed. James Tully (Indianapolis: Hackett Publishing, 1983), 51. Tully's modern edition is based on William Popple's 1689 English translation of Locke's Epistola de Tolerantia.

35 Damaris Masham to Jean Le Clerc, 12 January 1705; in the Amsterdam University Library (UVA), MS J.57.a.

${ }^{36}$ Damaris Masham to Jean Le Clerc, 12 January 1705; in the Amsterdam University Library (UVA), MS J.57.a. 
${ }^{37}$ Masham echoes Locke's definition of virtue in the Essay concerning Human Understanding (1689). In that work, Locke suggests that 'Vertue be taken for Actions conformable to God's Will, or to the Rule prescribed by God, which is the true and only measure of Vertue'; see John Locke, An Essay Concerning Human Understanding, ed. Peter H. Nidditch (Oxford: Clarendon Press, 1979), I.iii.18.

${ }^{38}$ Damaris Masham to Gottfried Wilhelm Leibniz, 8 August 1704; in Gottfried Wilhelm Leibniz, Die Philosophischen Schriften von Gottfried Wilhelm Leibniz, ed. C. I. Gerhardt (Berlin: Georg Olms Hildesheim, 1960), vol. III, 361.

${ }^{39}$ Locke, Letter concerning Toleration, 26.

${ }^{40}$ Locke, Letter concerning Toleration, 26.

${ }^{41}$ Locke, Letter concerning Toleration, 27.

${ }^{42}$ Locke, Letter concerning Toleration, 27. Given Locke's empiricist commitments, and the fact that here his emphasis is on 'the nature of the understanding', 'light' probably refers to the light of reflection, and 'evidence' the evidence of the senses.

${ }^{43}$ Locke, Letter concerning Toleration, 37.

${ }^{44}$ Locke, Letter concerning Toleration, 27.

${ }^{45}$ Locke, Letter concerning Toleration, 28.

${ }^{46}$ Locke, Letter concerning Toleration, 38.

${ }^{47}$ Locke, Letter concerning Toleration, 52.

${ }^{48}$ Masham says that 'To see what light we receive from Nature to direct our Actions, and how far we are Naturally able to obey that Light, Men must be consider'd purely as in the state of Nature, viz. as having no extrinsick Law to direct them, but indu'd only with a faculty of comparing their distant Ideas by intermediate Ones, and Thence of deducing, 
or inferring one thing from another, whereby our Knowledge immediately received from Sense, or Reflection, is inlarg'd to a view of Truths remote, or future' (OT, 60-62). Here Masham's concept of the state of nature accords with Locke's in the Two Treatises, to the extent that it is a state without civil laws to direct human actions, and yet human beings in this condition are still subject to the law of reason.

${ }^{49}$ Locke, Letter concerning Toleration, 51.

${ }^{50}$ Locke, Letter concerning Toleration, 28.

${ }^{51}$ Locke, Letter concerning Toleration, 51.

52 John Locke, Paraphrase and Notes on the First Epistle of St Paul to the Corinthians

(London: Awnsham and John Churchill, 1706), 66.

53 Ibid.

${ }^{54}$ Ibid.

${ }^{55}$ Ibid.

${ }^{56}$ Ibid.

57 Ibid.

${ }^{58}$ By contrast, Masham's contemporary Mary Astell does explicitly challenge Locke's remarks about women in the Paraphrase and Notes. On this topic, see Mark Goldie, 'Mary Astell and John Locke,', in Mary Astell: Reason, Gender, Faith, ed. William Kolbrener and Michal Michelson (Aldershot: Ashgate, 2007), 65-85.

${ }^{59}$ This paper was partly completed during my tenure as an Australian Research Council Postdoctoral Fellow in the School of Philosophy and Bioethics at Monash University, Melbourne, in 2007. I am extremely grateful to the ARC for their financial support. I would also like to thank James Buickerood, who first suggested to me that Masham was a 
tolerationist thinker; and Jillian Britton and Leigh McKinnon for their helpful translations. 